\title{
AAA ELECTIVE TREATMENT INDICATION TACTICS IN EVAR ERA
}

\author{
Petr Utíkala, Martin Köcher ${ }^{\mathrm{b}}$, Jiřina Koutnác, Petr Bachleda ${ }^{\mathrm{a}}$, Petr Dráča ${ }^{\mathrm{a}}$, Marie Černád, \\ Eva Buriánkovád
}

\author{
a 2nd Clinic of Surgery, Teaching Hospital Olomouc \\ ${ }^{b}$ Clinic of Radiology, Teaching Hospital Král. Vinohrady Praha \\ Clinic of Anestesiology, Teaching Hospital Olomouc \\ d Clinic of Radiology, Teaching Hospital Olomouc, Czech Republic \\ e-mail: petr.utikal@fnol.cz
}

Received: October 10, 2004; Accepted: November 6, 2004

Key words: Aneurysm/Aorta/Indications/Strategy/Surgery/Endovascular/Combined/Mortality/Morbidity

The authors describe their indication tactics for AAA elective treatment. Based on one-month morbidity and mortality they evaluate the results obtained in the past six years and compare the methods of open surgery, endovascular repair and combined strategy in AAAs elective repair.

\section{INTRODUCTION}

All infrarenal abdominal aortic aneurysms (AAAs) should be indicated for elective treatment. Active approach to AAA is based on its fatal prognosis and high difference between sad urgent and acceptable elective repair mortality ${ }^{1-7}$. In order to provide acceptable results, the risk of the elective repair has to be significantly lower than the risk of AAA rupture ${ }^{7,8}$. Open surgery (OS) has remained the standard of care in AAA elective treatment ${ }^{9}$. During the last decade, endovascular stentgrafting (EVAR) highly influenced the indications for AAA elective treatment ${ }^{10-12}$. This miniinvasive and hemodynamically less loading method has extended the elective treatment posibilities of AAA patients who show a high operating risk and are unfit for open surgery ${ }^{13-15}$. Another AAA treatment possibility, based on primary association of both of the previous methods, is the combined strategy (CS) for AAA of complicated morphology for $\operatorname{EVAR}^{16}$ (Fig. 1). The type of AAA repair is determined by the patient's individual operating risk first of all ${ }^{1}$.

\section{METHOD}

From April 1996 to September 2002 we investigated 304 patients with asymptomatic AAA (Table 1.). Open surgery was indicated in 115 patients $(n=38 \%), 128$ patients $(\mathrm{n}=43 \%)$ were treated endovascularly ${ }^{16-20}$. Indication for elective treatment and the way of repair were determined according to patients' life expectancy, condition (ASA classification) and AAA morphlogy analyses ${ }^{7,8,21-23}$ (Fig. 2). Low operating risk patients (ASA II) $(n=105)$ were mostly indicated directly for OS $(n=87)$, only some of them with suitable AAA morphology were considered for EVAR $(n=18)$. High operating risk patients (ASA III, IV) $(n=169)$ were primarily evaluated according to AAA morphology. Those with suitable AAA morphology for EVAR were treated endovascularly $(n=85)$. Patients with less suitable AAA morphology, but not so unfit, were indicated for OS $(n=28)$, unfit patients were treated by combined endovascular/surgical approach $(\mathrm{CS})(n=25$, $23 \%$ ) (Table 2.). 31 unfit patients with totally unsuitable AAA morphology $(n=10 \%)$ were observed and indicated only for urgent OS during the time $(n=11) .30$ low life expectancy patients $(n=9 \%)$ were primarily excluded from indication for elective AAA treatment.

\section{RESULTS}

Technical success was $100 \%$ in the OS and CS groups. In the EVAR group, primary technical success of $91 \%$ was achieved, secondary - assisted-technical success was $98.3 \%{ }^{1}$. There were no severe technical-surgical complications in any of the groups. The rate of cardiac and pulmonary complications was higher in the OS group $(\mathrm{n}=$ $14.7 \%$ ) versus the EVAR group ( $n=7.5 \%$ ) (Table 3.$)$. One-month mortality of $4.1 \%(n=10)$ in all treated groups was related to concomitant diseases. It was $5.2 \%(n=6)$ in the OS group and $3.1 \%(n=4)$ in the EVAR group. In the ASA III group it was $14.2 \%$ for OS versus $2.8 \%$ for the EVAR group (Table 4.). In the observed group, $35 \%$ of the patients needed urgent surgery (mortality of $75 \%$ ). $80 \%$ of low life expectancy untreated patients died of concomitant diseases within six months. 


\section{DISCUSSION}

All patients with suspected AAA should be investigated and all patients with proved AAA should be evaluated in terms of repair indication. The basic condition for indicating AAA patiens for elective treatment is their life expectancy and the patient's individual operating risk arising from the particular type of repair $^{2-4,7,8}$. The risk of AAA rupture should be higher than the risk of death of concomitant diseases during the time or during the postoperative period ${ }^{7,8}$. Contraindications for elective repair are mostly relative; AAA repair is absolutely contraindicated in patients with life expectancy below one year $^{8}$. At present, classical open surgery (OS), endovas-
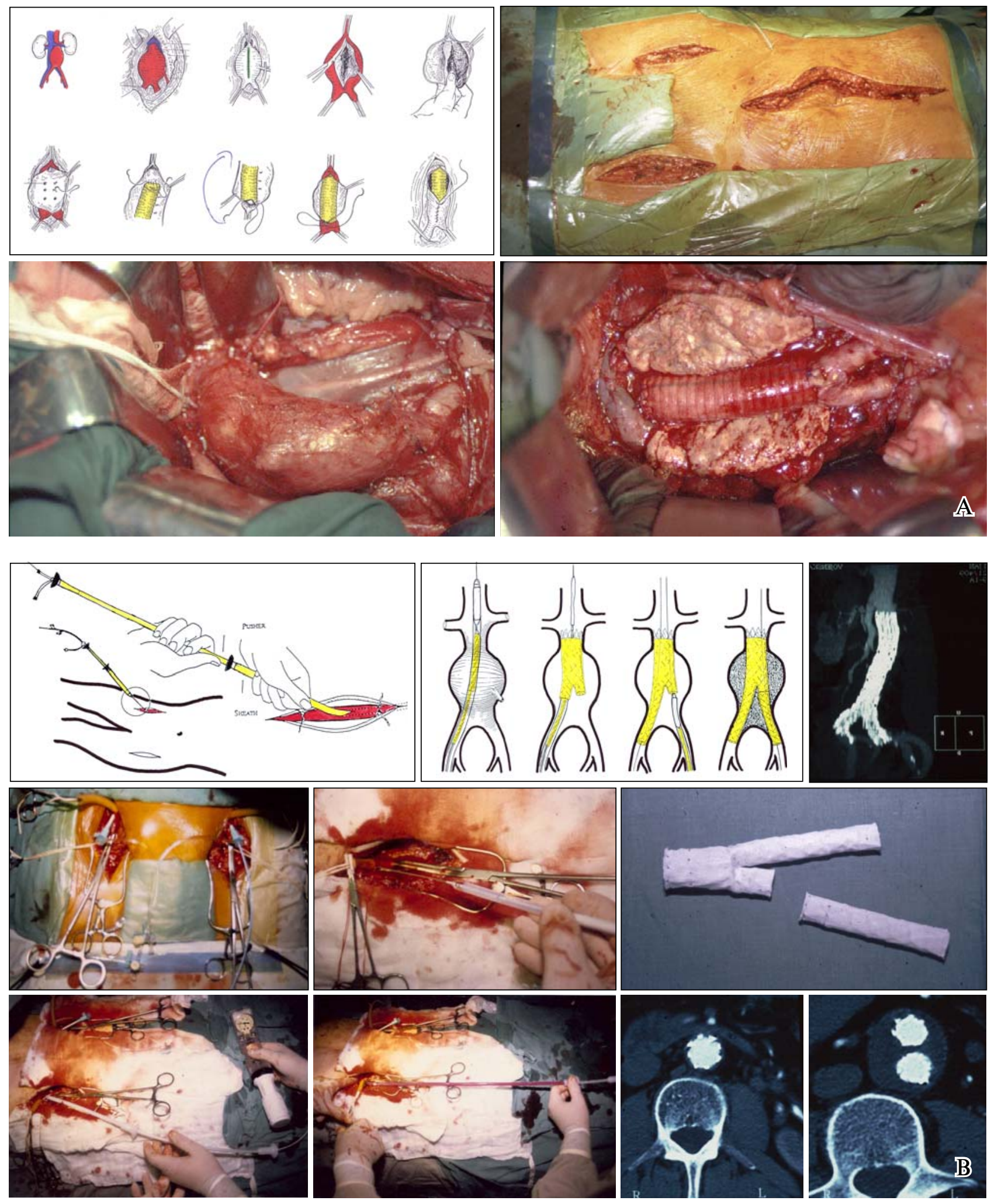

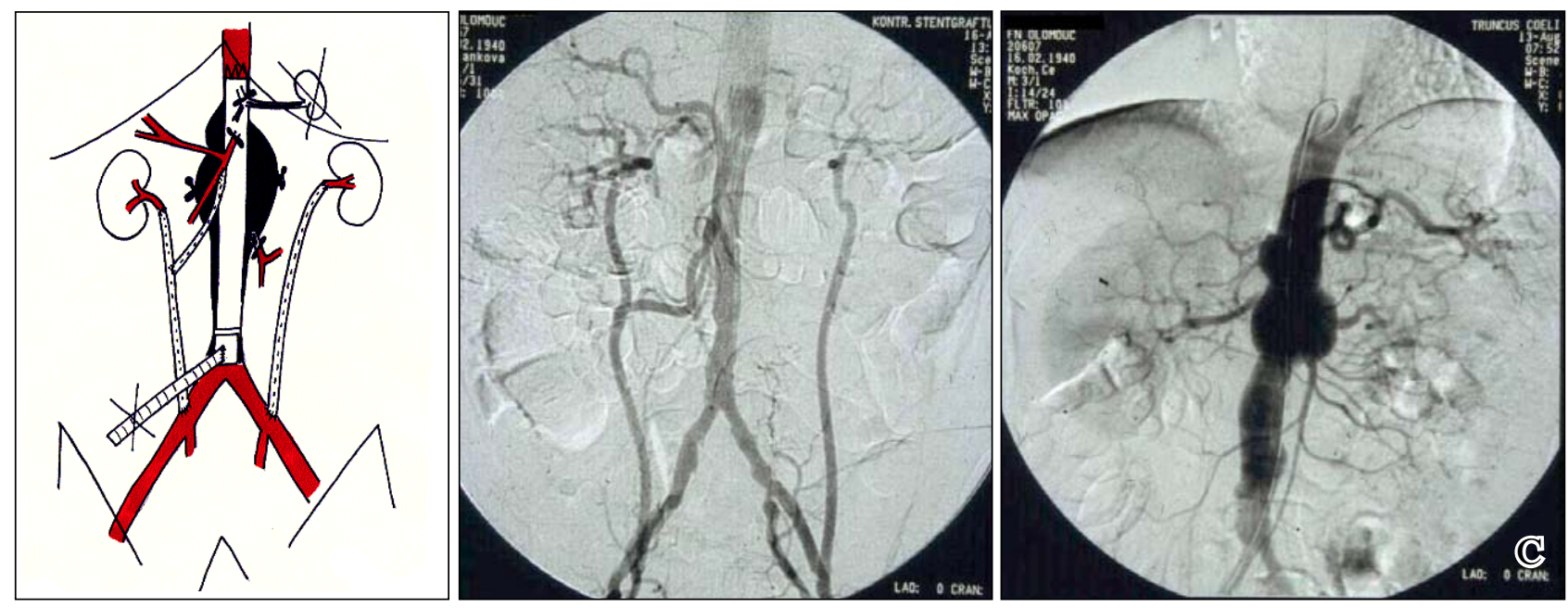

Fig. 1. AAA elective treatment possibilities at present: A: Open surgery, B: EVAR, C: Combined strategy

cular repair (EVAR) and combined strategy (CS) are the three possibilities of AAA repair (Fig. 1). Observation does not mean "no treatment". It is waiting for the right timing of repair, when the risk of rupture will be higher than the risk of repair. Elective OS has acceptable morbidity (10-15\%) and mortality (2-8\%) but only in fit patients (ASA II). Hemodynamically loading aortal clamping and invasivity significantly increase the morbidity $(40 \%)$ and mortality $(19 \%)$ rates in high operating risk patients (ASA III, IV) ${ }^{6,13-15}$. These patients comprise a significant portion of AAA patients. Therefore, the hemodynamically less loading and miniinvasive EVAR, with acceptable mortality also in high operating risk patients $(4.7 \%)$, has come into focus in the last decade ${ }^{12-15}$. Unfortunately, EVAR has technical limitations caused by the present stent-graft system construction and the indication depends on AAA morphology. Not all AAAs could be endovascularly treated ${ }^{21-23}$. That is why all questions in preoperative decision as to the type of treatment are connected with the patient risk and AAA morphology. The advantages of both methods are combined and the disadvantages eliminated in $\mathrm{CS}^{16}$ (Fig. 2). The use of these endovascular techniques (EVAR and CS) seems to be the reason why only $10 \%$ of the patients are rejected from the group of AAA patients with tendency to treat.

Low operating risk AAA patients indicated for EVAR were the following: patients after repeated laparotomies, before another severe and complicated surgery of the abdominal cavity, young men with the need of preaortic vegetative plex saving (sexual dysfunction prevention). The best comparision of OS and EVAR mortality and morbidity rates is in the ASA III group of AAA patients and also when we compare OS in ASA II versus EVAR in the ASA III group ${ }^{13-15,24-26}$. The increased invasiveness of the combined strategy associated with additional open surgery leads to higher, yet acceptable morbitidy. We have to underline that it is mostly patients of high operating risk that are treated endovascularly.

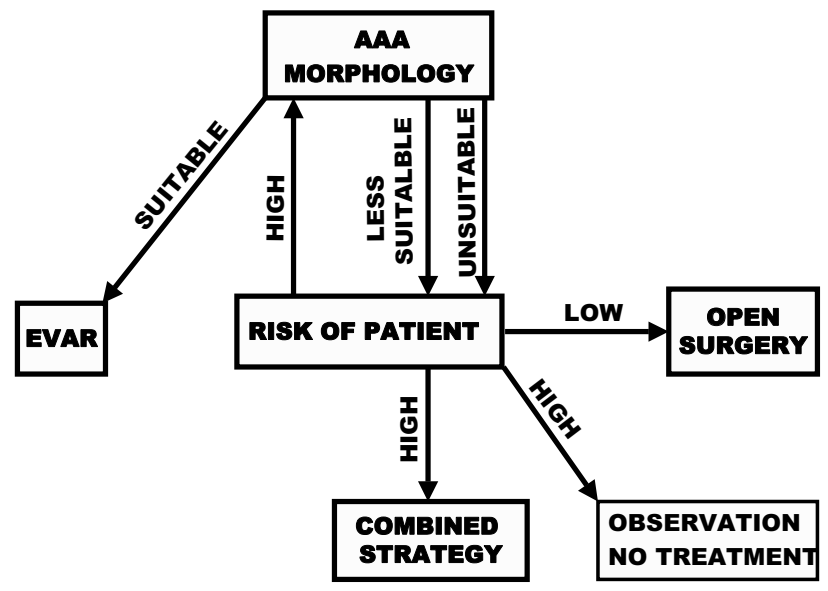

Fig. 2. AAA patients (with good life expectancy) elective indication tactics

\section{CONCLUSION}

All our results may be successfully compared to the results published by other clinics.

Based on the evaluation of our indication tactics of AAA elective treatment according to one-month results, we can confirm:

The endovascular approach is of principal significance for successful AAA elective treatment in high operating risk patients (ASA III, IV). The combined strategy is the method of choice in the morphologicaly complicated AAA repair in these patients. Classical open surgery is recomended in low operating risk patients (ASA II) only. 
Table 1. Indication of AAA patients for elective treatment April 1996 - September 2002

\begin{tabular}{|c|c|c|c|c|}
\hline INVESTIGATED & & & 304 & $100 \%$ \\
\hline $\begin{array}{l}\text { INDICATED FOR } \\
\text { ELECTIVE TREATM } \\
\uparrow \text { life expectancy }\end{array}$ & ENT & & 274 & $91 \%$ \\
\hline TREATED & & & 243 & $80 \%$ \\
\hline SURGERY & 115 & $47 \%$ & & \\
\hline EVAR & 128 & $53 \%$ & & \\
\hline $\mathrm{CS}$ & 25 & $10 \%$ & & \\
\hline $\begin{array}{l}\text { OBSERVED } \\
\uparrow \text { high operating risk } \\
\downarrow \text { AAA morphology }\end{array}$ & & & 31 & $10 \%$ \\
\hline $\begin{array}{l}\text { NOT TREATED } \\
\downarrow \text { life expectancy }\end{array}$ & & & 30 & $9 \%$ \\
\hline
\end{tabular}

Table 2. Indication of AAA patients for elective treatment Type of repair according to patients operating risk

\begin{tabular}{|c|c|c|c|}
\hline $\begin{array}{c}\text { PATIENTS } \\
243\end{array}$ & $\begin{array}{c}\text { SURGERY } \\
\text { EVAR }\end{array}$ & CS \\
\hline ASA II & $83 \%$ & 115 & \\
105 & 87 & 18 & \\
\hline ASA III & $28 \%$ & $72 \%$ & \\
98 & 28 & 70 & $10 / 14 \%$ \\
\hline ASA IV & - & $100 \%$ & \\
40 & - & 40 & $15 / 38 \%$ \\
\hline
\end{tabular}

Table 3. AAA elective treatment

- 30 days morbidity - cardiac and pulmonary Surgery in comparision to EVAR according to patients operating risk

\begin{tabular}{|c|c|c|c|}
\hline PATIENTS & SURGERY & EVAR & $\mathrm{CS}$ \\
\hline ASA II $\quad 8 / 105$ & $8 / 87$ & $0 / 18$ & \\
\hline $7.6 \%$ & $9 \%$ & $0 \%$ & \\
\hline ASA III $\quad 14 / 98$ & $9 / 28$ & $5 / 70$ & $2 / 10$ \\
\hline $14.2 \%$ & $32 \%$ & $7 \%$ & $50 \%$ \\
\hline ASA IV & & $4 / 40$ & $3 / 15$ \\
\hline $10 \%$ & & $10 \%$ & $20 \%$ \\
\hline $26 / 243$ & $17 / 115$ & $9 / 128$ & $5 / 25$ \\
\hline $10.6 \%$ & $14.7 \%$ & $7.5 \%$ & $20 \%$ \\
\hline
\end{tabular}

Table 4. AAA elective treatment - 30 days mortality Surgery in comparision to EVAR according to patients operating risk

\begin{tabular}{|c|c|c|c|}
\hline PATIENTS & SURGERY & EVAR & CS \\
\hline ASA II $3 / 105$ & $3 / 87$ & $0 / 18$ & \\
\hline $2.8 \%$ & $3.4 \%$ & $0 \%$ & \\
\hline ASA III $\quad 5 / 98$ & $4 / 28$ & $2 / 70$ & \\
\hline $5.1 \%$ & $14.2 \%$ & $2.8 \%$ & - \\
\hline ASA IV $\quad 2 / 40$ & & $2 / 40$ & \\
\hline $5 \%$ & - & $5 \%$ & - \\
\hline $10 / 243$ & $6 / 115$ & $4 / 128$ & \\
\hline $4.1 \%$ & $5.2 \%$ & $3.1 \%$ & - \\
\hline
\end{tabular}

\section{REFERENCES}

1. Samy AK, McBain G.(1993) Abdominal aortic aneurysms:ten years hospital population in the city of Glasgow. Eur J Vasc Surg 7, 561-566.

2. Budd JS, Finch DRA, Carter PG. (1990) A study of the mortality from ruptured abdominal aortic aneurysms in district comunity. Eur J Vasc Surg 11, 1-6.

3. Vardulaki KA, Prevost TC, Walker NM, Day NE, Wilmink AB, Quick CR. ( 1998) Growth rates and risk of rupture of abdominal aortic aneurysms. Br J Surg 85, 1674-1680.

4. Krupski WC. (1995) Arterial aneurysms. In: Rutherford RB.: Vascular surgery. Philadelphia, W.B. Sauders comp., 1025-1069.

5. Ernst CB. (1993) Abdominal aortic aneurysms. N Engl J Med 328, 1167-1172.

6. Blankensteijn JD. (2000) Mortality and morbidity rates after conventional abdominal aortic aneurysm repair. Semin Intervent Cardiol 5, 7-13.

7. Firt P, Hejnal J, Vaněk I. (1991) Cévní chirurgie. Praha, Avicenum, $148-159$.

8. Mohan IV, Harris PL. (2000) When not to operate for abdominal aortic aneurysms. Semin Intervent Cardiol 5, 15-19.

9. Dubost C, Allary M, Oeconomos N. (1952) Resection of an aneurysm of the abdominal aorta. Arch Surg 64, 405-408.

10. Parodi JC, Palmaz JC, Barone HD. (1991) Transfemoral intraluminal graft implantation for abdominal aortic aneurysms. Ann Vas Surg 5, 4912-499.

11. Volodos NL, Karpovich IP, Troyan VI. (1991) Clinical experience of the use of self-fixing synthetic prosthesis for remote endoprosthetics of the thoracic and abdominal aorta and iliac arteries through the femoral artery and as intraoperative endoprosthesis for aorta reconstruction. VASA Suppl 33, 93-95.

12. Parodi JC, Ferreira M. (2000) Why endovascular abdominal aortic aneurysm repair? Semin Intervent Cardiol 5, 3-6.

13. Teufelsbauer H, Prusa AM, Wolff K, Polterauer P, Nanobashvili J, Prager M, Holzenbein T, Thurnher S, Lammer J, Schemper M, Kretschmer G, Huk I. (2002) Endovascular stent-grafting versus open surgical operation in patients with infrarenal aortic aeurysms. A propensity score-adjusted analysis. Circulation 106, 782-787.

14. Teufelsbauer H, Prusa AM, Wolff K, Sahal M, Polterauer P, Lammer J, Holzenbein T, Kretschmer G, Huk I. (2003) The impact of endovascular stent-grafting on reducing mortality rates after surgical treatment of abdominal aortic aneurysms. Eur J Vasc Endovas Surg 26, 494-500.

15. May J, White GH, Yu W, Ly CN, Waugh R, Stephen MS. (1998) Concurent comparison of endoluminal versus open repair in the treatment of abdominal aortic aneurysms" analysis of 303 patients by life-table method. J Vasc Surg 27, 213-221. 
16. Utíkal P, Köcher M, Bachleda P, Dráč P, Buriánková E, Kojecký Z, Ürge J. (2001) Léčba AAA na přelomu tisíciletí - stentgrafting - role cévního chirurga. Prakt Flebol 10(3), 111-113.

17. Köcher M, Utíkal P, Sekanina Z, Bachleda P, Novotný J. (1998) Léčba AAA bifurkačními stentgrafty Ella - první zkušenosti. Rozhl Chir 77(6), 260-266.

18. Utíkal P, Köcher M, Bachleda P, Novotný J, Ürge J, Dráč P. (2000) Tř́leté zkušenosti se stentgraftingem AAA ve FN UP v Olomouci. Prakt flebol 9(4), 175-179.

19. Köcher M, Utíkal P, Buriánková E, Koutná J, Bachleda P, Novotný J, Heřman M, Benýšek V, Bučil J, Černá M. (2001) Čtyřleté zkušenosti se stentgraftem Ella v endovaskulární léčbě AAA. Čes Radiol 55(3), 159-166.

20. Köcher M, Utíkal $P$, , Koutná J, Bachleda P, Buriánková E, Heřman M, Bučil J, Benýšek V, Černá M, Kojecký Z.(2004) Endovascular treatment of abdominal aortic aneurysms-6years of experience with Ella stent-graft system. Eur J of Radiol 51, 181-188.

21. Schumacher H, Allenberg JR, Eckstein HH. (1996) Morphological classification of abdominal aortic aneurysm in selection of patients for endovascular grafting. Br J Surg 83, 949-950.
22. Carpenter JP, Baum RA, Barker CF. (2001) Impact of exclusion criteria on patient selection for endovascular abdominal aortic aneurysm repair. J Vasc Surg 34, 1050-1054.

23. Schumacher H, Eckstein HH, Kallinowski F. Morphometry and classification in abdominal aortic aneurysms: patient selection for endovascular and open surgery. J Endovasc Surg 4, 39-44.

24. Hill BB, Wolf YG, Lee WA, Arko FR, Olcott C, Schubart PJ, Dalman RL, Harris EJ, Fogarty TJ, Zarins CK. (2002) Open versus endovascular AAA repair in patients who are morphological candidates for endovascular treatment. J Endovasc Ther 9, 255-261.

25. Zarins CK, White RA, Schwarten D, Kiney E, Dietrich TB, Hodgson KJ. ( 1999) AneuRx stent-graft versus open surgical repair of abdominal aneurysms: multicentre prospective clinical trial. J Vasc Surg 29, 292-308.

26. Becquemin JP, Bourriez A, D'Audiffret A, Zubilewitz T, Kobeiter H, Allaire E, Melliére D, Desgranges P. Mid-term results of endovascular versus open repair for abdominal aortic aneurysms in patients anatomically suitable for endovascular repair. Eur $\mathbf{J}$ Endovasc Surg 19, 656-661. 